\title{
Research on the Deep Integration of Ideological and Political Theory Course and Student Work in Colleges and Universities
}

\author{
Lei Yanfei ${ }^{1}$ \\ ${ }^{1}$ (School of Education Science in Guangxi Science \& Technology Normal University, Guangxi, Laibin \\ 546199)
}

\begin{abstract}
The teaching of ideological and political theory course and student work are important components of ideological and political work in colleges and universities. Currently, there are problems emerging from ideological and political education on college students, including separation of education concepts, absence of management mechanisms, disconnection between theory and practice, and ineffective integration of the work team with estrangement. This paper focused on facilitating the deep integration of ideological and political theory course, and student work to enhance the effectiveness of ideological and political work in colleges and universities through continuous improvement of cultivation mechanism, reform of teaching education and methods, proactive exploration of practical teaching modes and deep integration of teaching teams, etc.
\end{abstract}

\section{Introduction}

General Secretary Xi Jinping emphasized ideological and political work in colleges and universities at the national conference as follows: To do a good job in ideological and political work of colleges and universities, we must abide by the law of ideological and political work, of imparting knowledge and cultivating people and of students' growth so as to keep improving their working capability and level. While the "three laws" are being observed, ideological and political education work among college students can be well performed. We should give full play to the synergetic cultivation of ideological and political theory course (hereinafter abbreviated as "ideo-political course") and student management, in which new methods and paths need to be explored through the integrated development between them in order to address the fundamental issue of what kind of people to cultivate, how to cultivate them and whom they work for. We need to help college students improve their overall quality to provide a strong motivation for cultivating builders and successors in the cause of socialism with Chinese characteristics.

\section{Value of the Deep Integration of Ideo-political Courses and Student Work in Colleges and Universities in this Era}

Ideo-political education on college students is a systematic project that comprises important subsystems of ideo-political courses and student management to be supplemented and internally unified, which plays an indispensable role in the cultivation of people. Firstly, it is conductive to returning to the essence. With ideo-political education courses provided in colleges and universities such as Fundamental Principles of Marxism, Outline of Mao Zedong Thought and the Theoretical System of Socialism with Chinese Characteristics and Situation and Policy, college students are educated with theoretical systems of Marxism-Leninism, Mao Zedong Thought, Deng Xiaoping Theory, the important thought of "Three Represents" and socialism with Chinese characteristics. They should be guided to have a correct outlook on the world and development in China with Marxist theory so as to devote themselves to the great course of realizing the China Dream while holding fast to the "Four Confidence". Student work in colleges and universities also plays a significant role in the guidance of ideological behavior. Only deep integration of the two can contribute to the sublimation from theory to practice and practice to theory. Secondly, it is conductive to the Formation of Educational Synergy. The ideo-political course is a vital channel for college students to learn Marxism-Leninism theory. Through bilateral teaching activities, it has undertaken an important task of imparting theory of socialism with Chinese characteristics to college students. For the student work, students receive ideological, political and moral education through a host of thematic education activities and daily affair management under the guidance of student cadres of the Party and Youth League organization. The two major subsystems give full play to the advantages in their respective fields to enhance the comprehensive quality of contemporary college students. Thirdly, it is conductive to the consistence of words and deeds. People's thought and ideas involve a complicated process with gradual formation of "cognition, emotion, thinking, will and behavior". Ideo-political courses aim to guide the "cognition" of college students during the 
teaching process, while student work guides college students" "behavior" in the practical work. Advantages of the two are complemented to achieve the consistence of words and deeds, with the ultimate goal of cultivating talents with both ability and political integrity. Fourthly, it is conducive to improving the quality of teaching teams. With strengthened communication, exchanges and cooperation between the two teams, we can improve the theoretical research and student management between them and train the teams into experts and professional teachers so as to form an educational synergy and a "large ideo-political" pattern. We should cultivate and guide college students to identify major events at home and abroad, build core values of socialist and incorporate their own ideals into the construction and development of the country in a down-to-earth manner.

\section{Problems of the Deep Integration between Ideo-Political Courses and Student Work in Colleges and Universities}

Deep integration and coordinated cultivation of ideo-political courses and student management work are of vital theoretical and practical significance. Due to multifaceted factors, many colleges and universities act willfully rendering the phenomenon of "imparting knowledge opposite to educating people". It is manifested by: First, separation of educational concepts. For a long time, the content of ideo-political classes has given people an impression that it is profound but boring theoretical knowledge, a type of theoretical education, obscure in spite of considerable recitation. Besides, the common "cramming" teaching mode of ideo-political classes ignores the idea development and behavioral changes of students after theoretical education, resulting in an unsatisfied teaching result. Student management work has long been centered on daily affair management by instructors and class teachers who can not enhance their own theoretical accomplishments due to a limited time and energy for learning. Therefore, they lack ideological awareness to guide students theoretically with less in-depth heart-to-heart talks with students in daily life, and therefore the management work fails to reach the bottom of their hearts. This kind of concept deviation makes theoretical education and management-oriented education go in separate ways. Second, absence of management mechanisms. Due to insufficient attention of leaders in colleges and universities, the ideo-political courses and student work are unable to realize deep integration that is also restricted by multiple subjective and objective factors. For example, instruction of ideo-political courses in certain colleges and universities is not in the charge of the party committee. From the perspective of traditional ideas, such courses are in the scope of teaching activities for which the president shall be responsible. Such concept makes deep integration of ideo-political courses and student work lack a solid foundation. To achieve deep integration of ideo-political courses and student work in colleges and universities, the party committee of colleges and universities shall coordinate the efforts of all sides to plan and arrange the ideological and political education for college students. Third, disconnection between theory and practice. In recent years, ideo-political courses have focused on creating new models of practical teaching, developing myriads of teaching activities in social practice such as campus practice, social survey and voluntary services, etc. manifested by student management work. For example, while learning core values of socialists of socialist in the teaching of ideo-political courses, students are usually organized to participate in practical activities, from which they are able to gain a deeper understanding and perception of such theory. Hence, the fulfillment of core values of socialist should be combined with the activities of student society under the assistance of student affair administrative department. With effective combination of the two, "talent training from the perspective of three holistic education" (namely full-staff education, whole-process education and all-round education) can be better realized. However, the two departments operate in their own ways while carrying out activities without communication and exchanges, thus resulting in repetitive organization of thematic activities and a waste of educational resources. Fourth, estrangement between the work teams. Ideo-political teachers in many colleges and universities focus on giving lessons, but the contents of classroom teaching without innovation is not life-oriented and generalized. With the lectures not "out of the classroom and the campus", their ideo-political courses are not favored by students. Student management work led by instructors and class teachers is carried out by virtue of experience, and there is no overlap with ideo-political teachers. Therefore, it is an arduous task of integrating the teaching teams when they do not understand the work of each other and lack cooperation on the research projects, making them hard to interact in work.

\section{Ways to Realize Deep Integration of Ideo-Political Courses and Student Work in Colleges and Universities}

4.1 Establish a Concept of Education with Ideo-political Courses. "Thoughts are the forerunner of action", and they determine the direction of action. Only when the ideological understanding is correct, and the action is taken positively, can the correct behavioral effect be obtained. Wrong thinking and understanding are bound to cause failure results against the pattern of development of things. Ideological and political education work in colleges and universities is a systematic large project, where students, courses, classroom, campus culture, teachers and society, etc. are important components. It requires the mobilization of all educational resources to form an educational synergy and build a working model of ideological and political education through multi-party coordinated cultivation. In view of the current problems in the cooperation between ideo-political courses and student work, we should 
address the issue of "imparting knowledge opposite to educating people" and reverse the situation. First of all, only by raising awareness and deeply understanding the importance and immediate significance of coordinated cultivation between the two can we strengthen the sense of work responsibility and consciously devote ourselves to their cooperation. Whether it is ideo-political courses or daily management of students, the educational purpose of both is to do a good job in ideological and political education of college students. We should cultivate noble moral qualities of college student with firm ideals and belief, help them establish correct values, enhance their ability of analyzing and solving problems to resist decadent ideas and cultivate them into builders of the new era. Moreover, the methods and focus adopted by them are also different. As regard student management, instructors adopt a method of daily management practice characterized by family-style care, love and patience, while ideological and political course teachers apply a model of theoretical education manifested by reasoning enlightenment and emotional appeal. It can be said that student ideological management work can be better carried out under the theoretical guidance. The teaching work of ideo-political courses provides a theoretical support for the development of student work. Only by fully understanding the importance and immediate significance of coordinated cultivation between the two, can we truly change the status quo of them working independently and implement various guarantee mechanism and cooperation platforms. We can establish a cooperation model and form an educational synergy to effectively enhance the effectiveness of ideological and political education among college students.

\subsection{Constantly Innovate and Improve Cultivation} Mechanism. Common disciplinary properties are equipped by both ideo-political courses and student work. To perform well in the overall planning of ideological and political education of college students, all colleges and universities must adopt an overall concept of disciplines to establish and improve an integration between the two in order to realize unity between them. First of all, teachers should be organized by college and universities across the country to study the spirit of concerned documents, meetings and speeches made by the party and government about the ideological and political work under the lead of arty committees and presidents. Ideological and political teaching teams and instructors should digest relevant policy guidelines by focusing on the learning. During the learning process, party committees and leading group in colleges and universities should reach a high degree of consensus in ideo-political courses and student work and gain a deep understanding of the significance and necessity in the deep integration of the two. Meanwhile, it is necessary to create an atmosphere of in-depth integration between the ideo-political courses and student work through the publicity window of colleges and universities Besides, a dedicated agency in the charge of main college leaders under the joint leadership of secretary of party committee and the president should be established for deep integration of ideo-political courses and school work. The members can be composed by School Affairs Department, School of Marxism, Youth League Committee in School, Psychological Counseling Center and Secondary School, etc. Under the leadership of this organization, the ideo-political courses and student work are planned as a "board of chess" to further strengthen and coordinate ideo-political courses and student work in colleges and universities. To establish a party-government joint conference system, regular meetings should be held to discuss and communicate student work plan and ideo-political course teaching plan for each semester. Besides, resources need to be integrated for effective organization and instruction of ideo-political education activities among students, with the existing problems adjusted and optimized in teaching and management. We need to change the phenomenon of different leaders in charge of ideo-political courses and student work and acting on their ways with unified leadership management and scientific top-level design in order to improve the cooperation between different departments, to jointly cultivate students and to promote deep integration of the two in all respects.

\subsection{Reform the Teaching Content and Method.}

The teaching of ideo-political courses and student work both aim to educate college students with ideological and political education and cultivate talents with both ability and political integrity for the motherland. Under the premise of "three laws" and "talent training from the perspective of three holistic education", the course teaching characteristics and pattern of student management should be integrated for consideration. First, besides the instruction of Marxist theory in ideo-political classes, it is also necessary to publicize Marxist theory in student work by the means of party and league classes, class meeting and society, with the content and form complementing each other. Second, theoretical guidance should be made on the practical issues concerned by students in the teaching of ideo-political courses, for example, students' disagreement with Marxist theory, undesirable style of study and exam, wrong ethics and outlook on employment, etc. Student work should also focus on the hot spots and difficult problems concerned by students, organize thematic class meeting, current affair report meeting and practical activities, etc. as an extension and supplement of the classroom teaching. Third, teachers of ideo-political courses should value the cultivation and guidance of core values of socialist among college students, and the guidance on the extracurricular practice is of vital significance; student workers must accurately grasp the performance of college students in practicing the core values of socialist and timely correct bad behavior with ideological guidance.

Fourth, in the reform and innovation of teaching methods, we must follow the enlightening principles and reflect the dominant role of students and humanistic care and make theoretical contents easier to be accepted by students. For example, case analysis can be made on the hot spots and difficult problems concerned by students in 
their own fields; students can be organized to visit Revolutionary Memorial Hall and organize on-site experiential teaching through major activities and ceremonies to intensify the students' emotional experience onsite; ideological cognition of students from different perspectives can be improved by inviting outstanding and influential social personnel to participate in thematic discussions in and out of the classroom, online or offline; typical results can be theoretically improved in the student work and applied to the teaching practice of ideo-political courses. A myriad of forms can be used as regard the method of ideological and political education, involving multiple aspects of students' learning and life. However, the practical activities should be summarized and extracted to enhance the depth and effect of education.

\subsection{Positively Explore the Practical Teaching}

Mode. The work of ideological and political education in colleges and universities is very complicated. It requires theoretical education and practical verification. Hence, it is necessary to integrate element innovation on the basis of tradition and realize continuous summary and perfection in the practice to achieve deep integration of practical mechanism between ideo-political courses and student work in colleges and universities. One is the deep integration of the work process. Both parties should consider and perform the work from the perspective of improving the effect of ideological and political work among college students rather than on their own stances or from self-perspectives. They should be involved in mutual realms, jointly study and discuss effective methods and paths of ideo-political courses and student work. Teachers of ideo-political courses should learn more about the ideological life of college students and enhance the pertinence and affinity of teaching; student workers should understand the doubts of college students in the class with teachers of ideo-political courses and provide theoretical solutions and assistance in the daily management. The second is the deep integration of activities. Practice produces theory that guides practice. Equal importance should be attached to theoretical education in the teaching of ideo-political courses and practical cultivation of student work. Teachers of ideo-political courses should give attractive lessons to students and explain the theories by combining hot spots and difficult problems met by students in order to address their practical problems; while conducting the student work, teachers should combine practical thematic activities with theoretical teaching to deepen students' theoretical understanding in practice. To address actual problems under the function of ideological and political education in a permanent and lasting approach, it is necessary to realize the cause of problems. Therefore, whether it is teaching activities of ideo-political courses and student work, they are both major education carriers of ideological and political work among college students. For example, when it comes to the chapter on patriotism, experiential teaching can be carried out in ideo-political courses by taking students out of the classroom to visit the red revolutionary education base; cultural festival on
"May $4^{\text {th }}$ Youth Day" and other practical activities can be held on campus by Student Affair Department. Effective integration of the two can achieve resource sharing and enrich the form of course teaching to help students improve themselves.

\subsection{Vigorously Promote the Deep Integration of} the Team. Ideological and political education puts forward rather high requirements for teachers' professional quality and ability structure. As an ideological and political educator, he must maintain a high sense of responsibility and enthusiasm for his job, with solid professional theoretical knowledge and sound morality and ethics of teachers. With good organization and coordination, he should be capable of investigation, research and ideological publicity and active to cooperate with concerned departments to perform well in ideological and political education.

The person in charge of relevant department of the school, must train well the teachers of the two teams responsible for ideological and political courses and student work, and incorporate the people with dedication, ambition and ability into the two teams to respect, care about and help college students solve the problem in study, life, and thought. To enhance the vigor and vitality of ideological and political education team, we should enable them to communicate and interact with each other frequently. College instructors can be recruited to give ideo-political courses because they understand ideological moment of students and work close to students in the class, which can improve the effectiveness of ideo-political courses; meanwhile, teachers can engage in a part-time job of student management for they boast solid theoretical foundations and rich teaching experience, hence they can help college students address hot spots and difficult problems to optimize the structure of instructor team as a whole. The two teams in frequent exchanges and communication can merit from each other to enhance the effectiveness of ideological and educational education. The ideological and political education of college students should be comprehensive and sustainable, and the cooperation between the two teams must feature basic theoretical literacy and capability of coordinated cooperation. Currently, instructors in colleges and universities should have a certain ability to study and research in this major. However, student workers are not allowed to engage in deep research on their work and theoretical studying due to a busy schedule of handling trivial student affairs every day, which severely hinders their improvement of professional literacy. But teachers of ideo-political courses can help and guide student workers to consider and train practical problems from the perspective of professional disciplines, expand the scope of theoretical study and enhance the academic literacy and practical level of student workers.

In a word, colleges and universities should respond to the call of the Communist Party of China and the country under new circumstance, adhere to seeking truth from facts and integrate theory with practice. On the premise 
of socialism-oriented school management, we need to keep improving the mechanism of ideological and political work, innovate the method for ideological and political education and facilitate deep integration of ideo-political course instruction and student management work in colleges and universities. We should give full play to coordinated cultivation of the two, enhance the effectiveness of ideological and political education of college students and fully implement the spirit of General Secretary Xi Jinping' speech on moral education and people cultivation to realize the overall requirements of talent training from the perspective of "three holistic education".

\section{Acknowledgment}

Scientific Research Fund: Research on Policy Support and Implementation Effect of Allocation of Rural Teacher Resources in Ethnic Regions" of the 2018 Western China Pedagogy Project, National Social
Science Foundation of the "13th Five-year" plan (XMA180281).

\section{References:}

1. Song Deyuan, Yu Guangdong. Further discussion on the cooperation between student work and instruction of ideological and political theory course[J]. Education and Teaching Research, 2003, (6).

2. Li Wenying. Practical exploration of the integration mechanism of ideological and political theory course and student work[J]. Reform and Development, 2018, (4).

3. Yan Lili, Shao Lili. On the integration of college student work and ideological and political theory course $[\mathrm{J}]$. The Party Building and Ideological Education in Schools, 2020, (5). 